\title{
Using of immunomodulating substances in optimizing cucumber nutrition in protected soil conditions
}

\author{
Maria Selivanova, Timur Aysanov, Elena Romanenko, Elena Mironova, and Natalia \\ Esaulko $^{1}$
}

Stavropol State Agrarian University, 12 lane Zootehnicheskiy, Stavropol, 355017, Russia

\begin{abstract}
Studies on the influence of biologically active substances with immunomodulatory properties on the productivity of greenhouse cucumber were conducted in the winter-spring turnover of the sixth light zone in 20192020. The paper analyzes data on the prevalence of major diseases in cucumber plantings, the intensity of respiration and photosynthesis in plants, the level of yield and yielding of standard crop products, depending on the use of immunomodulating substances against the background of the main nutrition scheme. As a result of scientific research, it was found that the use of immunomodulators (arachidonic acid, hydroxycinnamic acids, triterpenic acids, salicylic acid) in the technology of cucumber cultivation activated the protective properties of plants against pathogens, contributed to the activation of the intensity of respiration, photosynthesis, obtaining an increased yields and the output of standard products.
\end{abstract}

\section{Introduction}

For agricultural crops, especially vegetable crops when grown in protected soil conditions, it is important to increase the environmental safety of plant protection systems from a number of diseases and pests without reducing their effectiveness. The list of chemical plant protection products includes many toxic substances for living organisms that can have a negative impact on agrobiocenoses due to the accumulation of residual amounts of harmful substances in products, environmental pollution, and, in general, violations of the natural mechanisms of self-regulation of agroecosystems [1]. The use of pesticides in conditions of intensive cultivation of vegetable crops in protected soil conditions is strictly regulated and is sought to be minimized. In this regard, in order to increase the greening of greenhouse crop cultivation technologies, much attention is paid to improving traditional technological processes.

As a result of the intensification of the protected soil industry, the presence of monoculture in most greenhouse plants, many varieties and hybrids of vegetable crops have reduced resistance to diseases, which increases the susceptibility of plants to adverse environmental conditions. Therefore, it is necessary to improve the existing technologies for growing vegetable crops and use growth regulators in them that have biologically active substances in their composition. Biologically active substances can have multifunctional properties: providing plants stress free conditions, adjusting the microclimate conditions, 
restraining the development of fungal and bacterial diseases of vegetable crops and other negative factors $[2,3,4,5]$. Compositions based on biologically active substances stimulate the course of physiological processes, the growth and development of plants, are able to increase the adaptive ability to adverse environmental factors, increase the immunity of the plant organism and resistance to phytopathogens $[6,7,8]$.

Biologically active substances that activate the protective properties of plants, contribute to increasing the resistance of plants to diseases and some pests, and are so - called inducers of immunity (otherwise-immunomodulators) are of great interest in the vegetable growing of protected soil. Most immunomodulators, in addition to their protective properties, have growth-stimulating properties. Rational use of immunomodulators can significantly reduce the use of traditional plant protection products, which undoubtedly ensures an increase in environmental cleanliness and safety of manufactured products $[9,10,11]$.

Phytoimmunocorrection is a promising method of reducing the harmfulness of pathogens. When stimulating their own immunity in plants, there is an induction of complex nonspecific resistance to diseases of various origins and other adverse environmental factors (drought, temperature stress, etc.) $[12,13]$.

In modern systems of protection of greenhouse crops from diseases, fungicidal and protective-stimulating drugs that activate mechanisms for increasing plant disease resistance at the biochemical level play an important role. Immunomodulating substances are used to prevent diseases of greenhouse crops, reduce their prevalence, they have a positive effect on the energy of germination and germination of seeds, stimulate root formation [14].

The aim of the research is to assess the effect of biologically active substances with immunomodulatory properties on the productivity of cucumber in protected soil conditions.

\section{Materials and methods}

The research was carried out in the winter-spring turnover in the winter glazed greenhouse of JSC "Solnechny", which is located in the Izobilnensky district of the Stavropol Territory and belongs to the sixth light zone. Objects of research: cucumber Bjorn F1, immunomodulators: arachidonic acid, hydroxycinnamic acids, triterpenic acids, salicylic acid.

Bjorn F1 (Originator "Enza Zaden" - the Netherlands) is a highly productive earlymaturing parthenocarpic hybrid that forms gherkin-type fruits. The hybrid is intended for growing in greenhouses and open ground. The hybrid plant forms the bulk of its crop on the main stem, slowly developing lateral shoots. The hybrid Bjorn F1 is characterized by stability, tying the fruits and not dropping the ovaries under stress. The fruits are cylindrical in shape, dark green in color, 10-12 cm long, weighing 100-120 g, they are characterized by increased shelf life and transportability.

The scheme of the experiment: 1 - Control (background); 2 - Background + arachidonic acid; 3 - Background + hydroxycinnamic acids; 4 - Background + triterpenic acids; 5 Background + salicylic acid.

The experience is one-factor, the scheme of the experience was built according to the method of organized repetitions, the repetition of the experience is 3-fold, the placement of plots in the experience is multi - tiered, the options within the repetition are randomized.

Immunomodulators were used as foliar top dressing in the phase of 2 real leaves and three times every 14 days: arachidonic acid $0.005 \%-0.5 \mathrm{~g} /$ ha, hydroxycoric acids (complex of acids: extract of Echinacea purpurea $-0.005 \%$ ) -0.02 1/ha, triterpenic acids (complex of acids: extract of Siberian larch in the composition of Novosil $-0.005 \%)-0.051 / \mathrm{ha}$, salicylic acid $0.005 \%-0.05 \mathrm{~kg} / \mathrm{ha}$.

Cucumbers were grown in a winter glazed greenhouse, in which the microclimate conditions were regulated. Mineral wool was used as a substrate. Seedlings were grown with 
the use of additional additional lighting, watering was carried out as necessary with $\mathrm{EC}=1.8$ $\mathrm{mS} / \mathrm{cm}, \mathrm{pH}=5.7$. Mats were fed two days before planting seedlings with a nutrient solution with $\mathrm{EC}=1.8 \mathrm{mS} / \mathrm{cm}, \mathrm{pH}=5.7$. Planting density -2.2 plants $/ \mathrm{m}^{2}$. During the cucumber growing season, nutrient solutions with a certain content of elements were used. Nutrient solutions were the control and background ones in all variants of the experiment. Indicators of the nutrient solution for watering plants after reseeding: $\mathrm{EC}=2.2-2.6 \mathrm{mS} / \mathrm{cm}, \mathrm{pH}=5.7$.

Methods of research and methods of processing the obtained data: the degree of prevalence of diseases; the biological effectiveness of the drug according to the modified Abbott formula; the intensity of plant respiration by the amount of carbon dioxide released (according to Boysen-Jensen); the intensity of plant photosynthesis by the assimilation flask method; the total yield in the dynamics of its receipt as the fruits ripen; the total yield of standard products per turnover.

The degree of disease prevalence was calculated by the formula: $P=(100 \mathrm{n}) / \mathrm{N}$, where $\mathrm{P}$ is the prevalence of the disease, $\% ; \mathrm{N}$ is the total number of plants in the sample; $\mathrm{n}$ is the number of diseased plants in the sample.

\section{Results and discussion}

The studied biologically active substances (arachidonic, hydroxycinnamic, triterpene and salicylic acids) have immunomodulatory and growth-stimulating properties. Immunomodulators with small doses of application can have a significant impact on the productivity of the plant, which is especially important in high-intensity technologies for growing vegetable crops in protected soil. The high efficiency of the use of biologically active substances with immunomodulatory properties in the cultivation of cucumber has been proven as a result of research.

Biologically active substances with immunomodulatory properties can activate an antiphytopathogenic effect at the cell level, which helps to strengthen the immune system of plants, increase the endurance of plants to adverse factors, in particular to resistance to diseases. Powdery mildew and ascochitosis were the most common diseases in cucumber plantings during the winter-spring turnover. The greatest prevalence among diseases was observed in powdery mildew: the degree of prevalence was greater than ascochitosis by 1.5 $7.5 \%$. The use of biologically active substances contributed to the activation of immune mechanisms in plants, as a result, the prevalence of diseases was less than in the control by 2.3-6.4\% (Table 1).

In experiments on field and vegetable crops of open ground, it has been proved that the use of arachidonic acid in the composition of growth regulators provides an increase in plant resistance to diseases by activating constitutional immunity [15]. As a result of the use of arachidonic acid in the experiment on cucumber, the lowest degree of disease prevalence was obtained: the indicators of powdery mildew were significantly lower compared to the control and the use of hydroxycinnamic, triterpene and salicylic acids by 0.1-6.4 0.3\%, ascochitosis - by $0.1-3.0 \%$, deviations from the average value according to the experiment were 1.51 4.89 and $0.87-2.13 \%$, respectively. The experimental error when accounting for powdery mildew was at the level of 0.04 , the accuracy of the experiment was 0.28 , when studying ascochitosis -0.06 and 0.64 , respectively.

In the studies, the biological effectiveness of immunomodulators in the fight against cucumber diseases was determined by comparing the percentage of affected plants in the treated area and in the control. The biological efficiency of the use of arachidonic acid was the highest in the experiment and, the difference compared to other options was $0.3-6.1 \%$. The biological effectiveness of the use of triterpene acids was less relative to arachidonic when taking into account powdery mildew by $0.3 \%$, ascochitosis - by $0.8 \%$, more than when treated with hydroxycinnamic and salicylic acids by $1.5-5.5 \%$. 
Table 1. Effect of immunomodulators on the prevalence of diseases in cucumber plantings

\begin{tabular}{|l|c|c|c|c|}
\hline \multirow{2}{*}{ Type } & \multicolumn{2}{|c|}{ Powdery mildew } & \multicolumn{2}{c|}{ Ascochitosis } \\
\cline { 2 - 5 } & $\begin{array}{c}\text { \% of } \\
\text { damaged } \\
\text { plants }\end{array}$ & $\begin{array}{c}\text { biological } \\
\text { efficacy of the } \\
\text { drug, \% }\end{array}$ & $\begin{array}{c}\% \text { of } \\
\text { damaged } \\
\text { plants }\end{array}$ & $\begin{array}{c}\text { biological } \\
\text { efficacy of the } \\
\text { drug, \% }\end{array}$ \\
\hline Control (background) & 18.9 & 33.8 & 8.4 & 26.3 \\
\hline $\begin{array}{l}\text { Background + } \\
\text { arachidonic acid }\end{array}$ & 12.5 & 30.3 & 8.9 & 21.8 \\
\hline $\begin{array}{l}\text { Background + } \\
\text { hydroxycinnamic } \\
\text { acids }\end{array}$ & 13.2 & 33.5 & 8.5 & 25.5 \\
\hline $\begin{array}{l}\text { Background + } \\
\text { triterpene acids }\end{array}$ & 12.6 & 32.3 & 9.1 & 20.2 \\
\hline $\begin{array}{l}\text { Background + } \\
\text { salicylic acid }\end{array}$ & 14.01 & - & 9.27 & - \\
\hline $\begin{array}{l}\text { Average value based } \\
\text { on experience, } \overline{\mathrm{x}}\end{array}$ & 0.04 & - & 0.06 & - \\
\hline Experiment errors, S $\overline{\mathrm{x}}$ & 0.28 & - & 0.64 & - \\
\hline $\begin{array}{l}\text { Accuracy of the } \\
\text { experiment, }\end{array}$ & 0.13 & - & 0.2 & - \\
\hline S $\overline{\mathrm{x}} \%$
\end{tabular}

Under the influence of treterpenic acids on plants, there is an increase in the activity of stress resistance genes, as a result, the formation of specific substances that are a link between environmental factors and the activity of individual genes or their blocks is observed in the plant. This statement is given in scientific sources of Russian scientists when studying the effect of treterpenic acids on spring barley.

The studied biologically active substances had a growth-stimulating function, which is confirmed by the activation of metabolic processes. The activation of physiological processes in the plant when using immunomodulators proves not only the influence of these substances on the expression of genes of protection against phytopathogens, but also genes responsible for the growth, development and action of phytohormones, which is indicated in a number of studies of Russian scientists on agricultural crops.

Treatment of cucumber plants with immunomodulators contributed to an increase in respiratory intensity relative to the control by $0.02-0.05 \mathrm{mg}$ of $\mathrm{CO}_{2} /$ hour $/ 100 \mathrm{~g}$. Studies have found that the best indicator of the respiratory intensity of cucumber plants was obtained as a result of the use of hydroxycinnamic acids $-1.24 \mathrm{mg} \mathrm{CO} /$ hour $/ 100 \mathrm{~g}$, a significant difference compared to the control was $0.05 \mathrm{mg} \mathrm{CO}_{2} /$ hour $/ 100 \mathrm{~g}$, relative to the average value according to experience $-0.03 \mathrm{mg} \mathrm{CO} /$ hour $/ 100 \mathrm{~g}$. The differences between the control and the use of salicylic acid were not significant and were within the range of $\mathrm{LSD}_{05}(0.02)$ and at the level of the average value according to the experiment $(1.21 \mathrm{mg} \mathrm{CO} / \mathrm{hour} / 100 \mathrm{~g})$ (Table 2).

Respiration and the intensity of photosynthesis are interrelated processes that depend on various agricultural techniques, especially the use of fertilizers and biologically active substances. As a result of the use of immunomodulators, the intensity of photosynthesis of cucumber plants significantly increased compared to the control by $0.03-0.05 \mathrm{mg}$ of $\mathrm{CO} 2 / \mathrm{m} 2 /$ hour. The maximum intensity of photosynthesis was observed when treating cucumber plants with hydroxycinnamic and triterpene acids $-0.43 \mathrm{mg} \mathrm{CO} / \mathrm{hour} / 100 \mathrm{~g}$, which significantly exceeded the control by $0.05 \mathrm{mg} \mathrm{CO} / \mathrm{m}^{2} /$ hour, the average value 
according to the experiment by $0.02 \mathrm{mg} \mathrm{CO} / \mathrm{m}^{2} /$ hour.

Table 2. Effect of immunomodulators on the physiological processes of cucumber

\begin{tabular}{|l|c|c|}
\hline \multicolumn{1}{|c|}{ Type } & $\begin{array}{c}\text { Respiratory rate, } \mathrm{mg} \\
\mathrm{CO}_{2} / \text { hour } / 100 \mathrm{~g}\end{array}$ & $\begin{array}{c}\text { Photosynthesis intensity, } \\
\mathrm{mg} \mathrm{CO}_{2} / \mathrm{m}^{2} / \text { hour }\end{array}$ \\
\hline Control (background) & 1.19 & 0.38 \\
\hline Background + arachidonic acid & 1.22 & 0.41 \\
\hline $\begin{array}{l}\text { Background + hydroxycinnamic } \\
\text { acids }\end{array}$ & 1.24 & 0.43 \\
\hline Background + triterpene acids & 1.23 & 0.43 \\
\hline Background + salicylic acid & 1.21 & 0.42 \\
\hline $\begin{array}{l}\text { Average value based on } \\
\text { experience, } \overline{\mathrm{x}}\end{array}$ & 1.21 & 0.41 \\
\hline LSD $_{05}$ & 0.02 & 0.02 \\
\hline
\end{tabular}

Biologically active substances in the experiment stimulated the growth and development of cucumber plants, which was reflected in an increase in crop yield. When using immunomodulators, the increase in cucumber yield compared to the control was $6.0-8.2 \%$, the difference was significant at $\mathrm{LSD}_{05}=0.16$. The highest yield of cucumber was obtained as a result of treatment of plants with hydroxycinnamic acids $-28.9 \mathrm{~kg} / \mathrm{m}^{2}$, which was more than other variants of the experiment by $0.3-1.2 \mathrm{~kg} / \mathrm{m}^{2}$. Deviations of the obtained yield data in comparison with the average value according to the experiment were in the range of 0.1 $1.5 \mathrm{~kg} / \mathrm{m}^{2}$ (Table 3).

Table 3. Effect of immunomodulators on cucumber yield

\begin{tabular}{|l|c|c|}
\hline \multicolumn{1}{|c|}{ Type } & Yield, $\mathrm{kg} / \mathrm{m}^{2}$ & $\begin{array}{c}\text { Output of standard } \\
\text { cucumber products, } \%\end{array}$ \\
\hline Control (background) & 26.7 & 86.2 \\
\hline Background + arachidonic acid & 28.4 & 91.8 \\
\hline Background + hydroxycinnamic acids & 28.9 & 92.5 \\
\hline Background + triterpene acids & 28.6 & 92.0 \\
\hline Background + salicylic acid & 28.3 & 91.7 \\
\hline Average value based on experience, $\overline{\mathrm{x}}$ & 28.2 & 90.8 \\
\hline Experiment errors, S $\overline{\mathrm{x}}$ & 0.05 & 0.03 \\
\hline $\begin{array}{l}\text { Accuracy of the experiment, } \\
\mathrm{S} \overline{\mathrm{x}} \%\end{array}$ & 0.17 & 0.03 \\
\hline LSD 05 & 0.16 & 0.11 \\
\hline
\end{tabular}

The immunomodulators had the properties of antistressants, which confirms the increase in the yield of standard cucumber products relative to the control. The output of standard products can be caused by the reaction of plants to various stressors and the natural aging of plants. The use of biologically active substances contributed to an increase in the stress resistance of cucumber plants and, as a result, a significant increase in the number of standard products compared to the control version by 5.5-6.3\%. The highest yield of standard products was noted when using hydroxycinnamic acids $-92.5 \%$, the difference compared to the average value according to experience was $1.7 \%$. 


\section{Conclusion}

The use of biologically active substances with the properties of immunomodulators (arachidonic acid, hydroxycinnamic acids, triterpenic acids, salicylic acid) in the technology of cucumber cultivation activated the protective properties of plants against pathogens, which was reflected in a decrease in the prevalence of powdery mildew and ascochitosis by 2.3$6.4 \%$ relative to the control with the biological effectiveness of substances of $20.2-33.8 \%$. Treatment of cucumber with immunomodulators contributed to an increase in the intensity of plant respiration compared to the control by $0.02-0.05 \mathrm{mg}$ of $\mathrm{CO}_{2} /$ hour $/ 100 \mathrm{~g}$, the intensity of photosynthesis - by $0.03-0.05 \mathrm{mg}$ of $\mathrm{CO}_{2} / \mathrm{m}^{2} /$ hour, obtaining an increase in yield and yield of standard products - by $6.0-8.2 \%$ and $5.5-6.3 \%$, respectively.

The high efficiency of the use of immunomodulators based on arachidonic, hydroxycinnamic, triterpene, salicylic acids in the technologies of growing agricultural crops has been confirmed in the studies of Russian and foreign scientists. Immunomodulators had a multifunctional effect on lettuce, cucumber, white cabbage, radish, potatoes, barley, wheat, had an adaptogenic protective effect and a growth-stimulating effect.

The results of scientific research of scientists and the data of our experience allow us to recommend the use of immunomodulators in agricultural technologies of greenhouse cucumber, as one of the components of biological protection of plants from diseases and a means of reducing stress load. Biologically active substances with immunomodulatory properties are effectively used both in pure form and as part of growth regulators and biological products, which, against the background of low doses of application, provides a significant increase in crop productivity.

\section{References}

1. C. Gong, L. Lin, Y. Wang, H. Wang, Y. Wang, E3S Web Conf., 136, 01018 (2019) https://doi.org/10.1051/e3sconf/201913601018

2. J. Li, H. Liu, H. Wang, J. Luo, X. Zhang, Z. Liu, Y. Zhang, L. Zhai, Q. Lei, T. Ren, Y. Li, M.A. Bashir, Agric. Water Manag. 210, 354-363 (2018) https://doi.org/10.1016/j.agwat.2018.08.036

3. M. Selivanova, T. Aysanov, E. Romanenko, E. Sosyura, N. Esaulko, M. German, IOP Conf. Ser.: Earth Environ. Sci., 315, 022022 (2019) https://doi.org/10.1088/1755$1315 / 315 / 2 / 022022$

4. F. Wang, X. Wang, N. Song. Agric. Ecosyst. Environ., 315, 107425 (2021) https://doi.org/10.1016/j.agee.2021.107425

5. K.A. Vakilian, J. Massah, Comp. Electron. Agric., 139, 153-163 (2017) https://doi.org/10.1016/j.compag.2017.05.012

6. E.A. Korenkova, E.I. Stepanova, E.V. Yakovleva, IOP Conf. Ser.: Earth Environ. Sci., 459, 032034 (2020) https://doi.org/10.1088/1755-1315/459/3/032034

7. Y. Li, J. Chi, J. Ao, X. Gao, X. Liu, Y. Sun, W. Zhu, Curr. Microbiol., 78(6), 2380-2390 (2021) https://doi.org/10.1007/s00284-021-02485-X

8. J. Nakkila, K. Jokinen, L. Sarkka, R. Tahvonen, Acta Hortic., 1013, 291-296 (2013) https://doi.org/10.17660/ActaHortic.2013.1013.35

9. M.V. Selivanova, O.Y. Lobankova, E.S. Romanenko, N.A. Esaulko, E.A. Sosyura, Biosci. Biotechnol. Res. Asia, 12(2), 1397-1004 (2015)

10. Y. Rouphael, M. Cardarelli, P. Bonini, S. De Pascale, G. Colla. Acta Hortic., 1268, 1317 (2020) https://doi.org/10.17660/ActaHortic.2020.1268.2

11. M. Selivanova, T. Aysanov, E. Romanenko, E. Mironova, N. Esaulko, M. German, E3S Web Conf., 164, 06022 (2020) https://doi.org/10.1051/e3sconf/202016406022

12. Y. Zhai, J.X. Zhu, T.M. Tan, J.P. Xu, A.R. Shen, X.B. Yang, J.L. Li, L.B. Zeng, L. Wei, 
BMC Microbiol., 21(1)., 75 (2021) https://doi.org/10.1186/s12866-021-02131-3

13. A. Sadeghi, P. Koobaz, H. Azimi, E. Karimi, A.R. Akbari, BioControl, 62 (6), 805-819 (2017) https://doi.org/10.1007/s10526-017-9838-4

14. Z.H. Hamid, R.J. Mansoor, IOP Conf. Ser.: Earth Environ. Sci., 388, 012085 (2019) https://doi.org/10.1088/1755-1315/388/1/012085

15. U. Zlotek, W. Wojcik, Sci. Hortic., 179, 16-20 (2014). https://doi.org/10.1016/j.scienta.2014.08.026 